\title{
Spatial Environment of Home, Stress Management, and Welfare of Family Living in Two-Level Marginal Regions
}

\author{
Euis Sunarti ${ }^{*}$ ), Nurul Fatwa ${ }^{2}$, Zulfa Rahmawati ${ }^{3}$, Winny Faramuli ${ }^{4}$, Dwifeny Ramadhany ${ }^{5}$ \\ $1,2,3,4,5$ Department of Family and Consumer Sciences, Faculty of Human Ecology, \\ IPB University, Bogor 16680, West Java, Indonesia \\ *) Corresponding author: euissunarti@apps.ipb.ac.id
}

\begin{abstract}
This study aims to analyze the home environment, stress management, and families' welfare in marginal areas. The study design was cross-sectional, and samples were selected by random cluster sampling, as many as 126 families consisting of 63 families from the very dense region (VDR> 200 people per Ha) and 63 families from a rather dense region (RDR, 121-160 people per Ha) in Bogor, West Java, Indonesia. The data were collected by interview using a questionnaire in March and April 2014 and analyzed using descriptive and comparison tests. The analysis showed that families in RDR had a lower density but had a higher crowd level than in VDR, so that families in RDR had to try harder to get non-physical privacy. RDR families had a higher source of stress, thus encouraging them to did more coping strategies. The analysis showed that families in RDR had higher objective well-being but lowered subjective welfare than families in VDR. Families in RDR had higher physical welfare and lowered social and psychological welfare than families in VDR. The research findings had implications for the importance of strengthening the family environment and developing research methodologies in the field of family ecology.
\end{abstract}

Keywords: crowding, density, family welfare, home environment, privacy

\begin{abstract}
Abstrak
Penelitian ini bertujuan untuk menganalisis lingkungan rumah, manajemen stres, dan kesejahteraan keluarga yang tinggal di daerah marginal. Disain penelitian adalah cross sectional, memilih contoh secara cluster random sebanyak 126 keluarga contoh terdiri atas 63 keluarga dari wilayah sangat padat (WSP> 200 orang per Ha) dan 63 keluarga dari wilayah agak padat (WAP, 121-160 orang per Ha) di Bogor, Jawa Barat, Indonesia. Pengumpulan data dilakukan dengan wawancara menggunakan kuesioner pada Bulan Maret dan April 2014, dianalisis menggunakan uji deskriptif dan perbandingan. Hasil analisis menunjukkan bahwa keluarga di WAP memiliki kepadatan yang lebih rendah, tetapi lebih tinggi tingkat kerumunannya dibandingkan di WSP, sehingga keluarga di WAP harus berusaha lebih keras untuk mendapatkan privasi non-fisik. Keluarga WAP memiliki sumber stres yang lebih tinggi, sehingga mendorong mereka untuk lebih banyak melakukan strategi koping. Hasil analisis lain menunjukkan keluarga di WAP memiliki kesejahteraan obyektif yang lebih tinggi, tetapi kesejahteraan subjektif lebih rendah daripada keluarga di WSP. Dengan menggunakan tiga klasifikasi kesejahteraan (fisik-sosial-psikologis), keluarga di WAP memiliki kesejahteraan fisik yang lebih tinggi, tetapi kesejahteraan sosial dan kesejahteraan psikologis yang lebih rendah dibandingkan keluarga di WSP. Temuan penelitian ini berimplikasi pada pentingnya penguatan lingkungan keluarga dan pengembangan metodologi penelitian dalam ranah ekologi keluarga.
\end{abstract}

Kata kunci: kepadatan, kesejahteraan keluarga, kesesakan, lingkungan rumah, privasi pribadi 


\section{Introduction}

Population development and socio-economic changes increase the urbanization of rural families to urban areas. Every family desires to achieve prosperity and quality of life, where one of the indicators is the quality of the home environment that the family occupies. The number and mobility of the population are causing some families to live and occupy a marginal region (riverbanks, suburban rail trains, and proneness), which originally was not legally owned. The region becomes dense, where the distances between home are very narrow and limited means of the environment, so be inclined slum and marginal settlements.

Marginal settlements are identified as residences located far from the main streets, potentially along the riverside, have less than the one-metre distance between houses, prone to disasters, and are categorised as informal settlements, beside squatters and slums. (Yudohusodo in Poedjioetami, 2005; WHO, 2003). UNHabitat (2015) defines informal settlements as dwellings where the occupants may have no home or land ownership or only informal rental housing, may suffer from a lack of basic services, and usually live in a treated area; poor urban areas are more common in developing country cities (Lirebo, 2006). According to Surtiani (2006), marginal settlements are characterized by interference region pollution, lack of clean water, inability to develop, and prone to flooding.

The home's environment contains many important factors affecting the sanity of settlements (Jackson in Bonnefoy, 2007). The spatial environment is described as the house's condition, including density, crowding, and privacy efforts. Density is an objective measurement in which the house size divided by the number of occupants in the house (Stokols in Melson, 1980). The more people living per house size, the higher goes the density (Sarwono, 1992). Crowding is the perception of the density level in the house (Stokols in Melson, 1980), a subjective assessment of one's solid condition (Stokols in Melson, 1980; Sarwono, 1992). Privacy is selective control done by individuals toward personal or community access (Altman in Melson, 1980). Privacy approach is conducted by measuring family members tendency to undisturbed solitude and is an important element for the family to develop the interaction between family members (Melson, 1980); in psychoanalytic terms is defined as a condition where a person seeks to protect the ego from intrusions (Sarwono, 1992).

Stress management can be described through three aspects, stressor, coping strategies, and symptoms of stress. Stressors are changes that occur in life that are a source of stress in the family (McCubbin \& Thompson, 1987); an event or occurrence that is a factor in the emergence of stress, both in the form of tension in the family, financial and business problems, changes in family and work problems, as well as problems with pain and family care. If seen from the ABC-X model of family stress (Hill in Rosino, 2016), variable A poses a stressor or stressful situation or event faced by a family. It can be any change in the family's social context, both positive and negative, and new situations or events require adjustments (Rosino, 2016). A coping strategy is a series of management activities and adaptations to cope with stressors. Finally, symptoms of stress are physical, psychological, cognitive and psychomotor (Maryam, 2010) conditions arising from inadequate coping strategies in the face of stressors.

As a condition in which all basic needs and developmental needs of the family can be met, the welfare of the family is the goal of family life (Sunarti, 2013b). This quite explained 
that a prosperous family is the goal of family development in Development of Population and Prosperous Family Indonesian Law Number 52 the Year 2009, amended from Law Number 10 Year 1992. However, social experts categorize welfare (or well-being) into subjective and objective welfare (Milligan, Fabian, Coope \& Errington, 2006), which gives a different emphasis but have complementary meanings (Sunarti, 2013b).

Referring to various studies, inadequate spatial and environmental conditions is a stressor that can lead to stress. It is suspected would interfere with the achievement of the well-being of the family. Strong relations between physical living environment and healthrelated variables found, that by improving living environment satisfaction, it can improve health in relation to stress, fatigue, and chronic low back pain (Nagasawa, Yamaguchi, Kato, \& Tanabe, 2018); that there is a link between positive health outcome and good housing (Baquyatan, 2015). On the other hand, crowded housing was associated with more health problems (Nkosi, Haman, Naicker, \& Mathee, 2019), an essential aspect of a family's quality of life. In addition, coping strategies positively influenced life satisfaction, while stress negatively influences life satisfaction (Zuhara, Muflikhati, \& Krisnatuti, 2017). As marginal settlement in urban areas typically has a low-quality environment and various housing issues, it is important to portray the spatial environment, stress management, and welfare of families living in areas with different density levels. This study aims to analyze the differences in the spatial environment, stress management and well-being of families living in the two denselevel areas in Bogor, West Java Province, Indonesia.

\section{Methods}

\section{Participant}

The design of this study was cross-sectional, while the location of the study is two villages in the district of Central Bogor, Babakan Pasar and Paledang, Bogor city, West Java Province. The location selected with non-probability sampling (purposive sampling), considering these villages fulfilled some of the criteria as marginal settlements. Both of these villages occupy the riverbanks, prone to flooding and landslides, mostly residential land owned by the government, with a high population density with the distance between the home being less than one metre, the environmental conditions of slums, and squatters. These two villages then categorized as very dense areas, Babakan Pasar (VDR, 10,211 inhabitants occupy 42 hectares or $>200$ persons per hectare) and a rather dense, Paledang (RDR, 10,236 inhabitants occupies 178 hectares or 121-160 persons per hectare) (BPS of Bogor City, 2014). The population of this study were intact families with 3-5 years old children living in marginal settlements, classified as VDR and RDR regions. A total of 126 families (each 63 per category region) were selected by cluster random sampling technique.

\section{Measurements}

The primary data collected includes family characteristics, the spatial environment of home (density, crowding, attempts to obtain personal privacy), stress management (stressors, coping strategies, stress symptoms), and the family's well-being using questionnaires. The following are the description of each variable: 
1) The spatial environment of home efforts

a. A questionnaire measured the density variable referred to Stokols in Melson (1980), where house size divided by the number of occupants in the house in ratio scale.

b. Crowding aspect instruments developed by researchers referring to Anjanie (2006) with Cronbach Alpha value of 0.909, measured with the semantic scale from 1-5 (very disagree to very agree) and separated into two categories: spatial and social aspects, each consisting of seven indicators. Crowding is physically shown if families feel less spacious home (1), feel claustrophobic inside the house (2), it is difficult move in the house (3), even when the door is opened, do not feel the room becomes wider (4), the room does not feel more spacious despite having set the location of furniture (5), the narrowness of the house leads to more emotional (6) and make easy stress (7). The social aspect of crowding measured from seven indicators which include: perceived housing condition cause children to be more aggressive (1), is not reassuring mood (2), be reluctant to interact with other people (3), making less than optimal work (4), was too many people in the house, (5), interrupted when a neighbour visiting home (6), so that sleep becomes an escape to avoid crowded (7).

c. Privacy efforts variables were constructed from family and environment theory (Altman in Melson, 1980). The effort of family members to obtain personal privacy, covering aspects of the physical environment and the nonphysical aspects. Privacy of the physical environment aspect include: always lock the door, always lock the bedroom door, the need to have my own space, and disturbed if a family member came into the room. Privacy through aspects of the non-physical environment includes: speak softly, using facial expressions and body language when a person does not want to be disturbed; do not want a lot of communicating themselves. The questions are built from a family and environmental approach and use a questionnaire. The answer choices are "Yes", "No" with a Cronbach Alpha value of 0.482 .

2) Stress management variables were measured with qualified original reliability, consist of:

a. The Source of stress (stressors) was elaborated using Family Life Event Inventory instruments (McCubbin \& Patterson in McCubbin \& Thompson, 1987). In this study, the stressor is measured from sources of tension in the family, finance and business, work and family, and illness and family care. The tension in the family comes from rising 1) the husband of time outside the home, 2) the time of wife outside the home, 3) emotional family members, 4) conjugal conflicts, 5) conflicts between children, 6) conflict with extended family and relatives, 7) the problem can not be resolved, 8) family task that can not be done, 9) children's activities outside the home, and 10) children are more unruly.

b. Coping strategies were measured using Family Coping Inventory (McCubbin et al. 1981 in McCubbin and Thompson, 1987). 
c. Mirrowsky and Ross (1987) measured symptoms of stress variable, categorized as physical and psychological symptoms. Type of physical symptoms recognized by more than 60 per cent of the families in the two regions is: the loss of appetites; experience difficulties in concentrating; sleeping problem; dizziness or headache; unwillingness to leave the house;

3) Family welfare and putting out more energy than usual.

a. Subjective well-being referred to the instrument developed by Sunarti (2013) classified into three dimensions, physical-economy, social, and psychological, with Cronbach Alpha value of 0.871 on developed instrument.

b. Objective well-being were assessed by basic needs compliance based on food, clothes, house, basic education and basic health and being modified from physical welfare in family strength by Sunarti (2003) (Cronbach's Alpha= 0.516).

\section{Analysis}

The data were collected by interviews using questionnaires from March to April 2014 in the city of Bogor. Data entry using Microsoft Excel and Statistical Package for Social Science (SPSS) and data were processed through cleaning, coding, editing, and scoring. Data analysis using descriptive analysis and comparison test. Descriptive analysis (mean, minimum value, maximum value, and percentage) to identify family characteristics. The Comparison test to identify the spatial environment of home efforts, stress management, and family welfare between VDR and RDR.

\section{Findings}

\section{Family Characteristics}

Family characteristics data are presented in Table 1 . The average length of education of both husbands and wives in two marginal areas has reached compulsory education ( 9 years), and there is no difference in the averages of the school year of both husbands $(10.14$ years in the VDR, 10.68 years in the RDR) and wives (9.76 years in VDR, and 9.95 years in RDR) in both regions. Still, wives (48\%) and husbands $(48.5 \%)$ do not meet the nine-year compulsory education. Although wives in a VDR have more work (36.5\%) compared to the wives in an RDR (25.4\%), but the average income of families in RDR higher (IDR 2.815.206) than family income in VDR (IDR 2,242,223). However, because the average family size in RDR higher ( $\mathrm{p}$-value $<0.05$ ) compared to the VDR, causing the average per capita income of the families in the RDR (IDR 575 450) lower than in VDR (IDR773,554), although it was not significant statistically. 
Table 1. Family characteristics according to density area and the result of comparison test

\begin{tabular}{|c|c|c|c|c|c|}
\hline \multirow{2}{*}{ Family characteristics } & \multicolumn{2}{|c|}{ RDR } & \multicolumn{2}{|c|}{ VDR } & \multirow{2}{*}{ P-Value } \\
\hline & Min-Max & Mean & Min-Max & Mean & \\
\hline Age of wife (yr) & $19-48$ & 32.84 & $20-47$ & 30.76 & 0.074 \\
\hline Age of husband (yr) & $24-59$ & 37.70 & $22-56$ & 35.56 & 0.103 \\
\hline Length (yr) of wife's education & $4-15$ & 9.95 & $6-15$ & 9.76 & 0.694 \\
\hline $\begin{array}{l}\text { Length (yr) of husband's } \\
\text { education }\end{array}$ & $6-17$ & 10.68 & $6-16$ & 10.14 & 0.103 \\
\hline Family size (ps) & $3-11$ & 4.98 & $3-8$ & 4.06 & $0.039 *$ \\
\hline Family Income (IDR/Mo) & & 2.815 .206 & & 2. 224.223 & 0.769 \\
\hline Income/capita (IDR/Mo) & & 575.450 & & 773.554 & 0.119 \\
\hline
\end{tabular}

Note: $*)$ significant at $\mathrm{p}<0.05$

\section{Spatial Environment of Home}

\section{Density}

Families who live in RDR and VDR feel the social aspect of crowding significantly ( $\mathrm{p}$-value $<0.05$ ). Families also use non-physical environment ( $\mathrm{p}$ value $<0.05$ ). The results showed that the marginalized families in RDR (if compared with VDR) have lower density, but high crowd ( $p$-value $<0.05$ ) especially on the social aspect of crowding), so families should put more efforts to obtain personal non-physical privacy (especially in non-physical aspect). Further descriptive analysis showed that since the families in VDR have a longer stay in the region (average 26 years) compared to families in the RDR (20.8 years), the density in the VDR is higher (averaging $8 \mathrm{~m}^{2}$ with a range of $0.8 \mathrm{~m}^{2}-40 \mathrm{~m}^{2}$ per capita) than the density in RDR (averaging 11:35 $\mathrm{m}^{2}$ per capita in the range of $0.75 \mathrm{~m}^{2}-40 \mathrm{~m}^{2}$ per capita).

Table 2. Environmental conditions based on the density of the area and the results of the comparison test

\begin{tabular}{lllll}
\hline No & Variable & RDR & VDR & P-Value \\
\hline 1 & Crowded & 61.90 & 55.10 & .059 \\
& Spatial aspect of crowded & 47.84 & 40.87 & .141 \\
& Social aspect of crowded & 44.22 & 35.32 & $.033^{*}$ \\
2 & Effort to obtain privacy & 61.90 & 55.10 & .087 \\
& Using physical environment & 45.63 & 40.87 & .376 \\
& Using non-physical environment & 83.60 & 74.07 & $.026^{*}$ \\
\hline
\end{tabular}

Note: *) significant at $\mathrm{p}<0.05$

\section{Crowding}

Crowding is measured by physical aspects of space and social aspects. Table 3 presented that the crowding perceived by families in the region RDR is higher ( $\mathrm{p}$-value $<0.06)$ compared to that felt by the family in the VDR, especially for crowding of the social aspects ( $p$-value $<0.05$ ). Furthermore, Table 3 and Figure 1 showed that social aspects of crowding were significantly different (RDR higher than VDR) on "feeling too many people in the house". However, it is a member of the nuclear family. 
Table 3. The average percentage of the social aspect of crowding according to family groups and the result of comparison test

\begin{tabular}{llrrr}
\hline \multirow{2}{*}{ No } & \multirow{2}{*}{ Variable } & \multicolumn{2}{c}{ Dense Region } & \\
\cline { 3 - 5 } & & RDR & VDR & P-Value \\
\hline 1. & Child becomes more aggresive & 68.75 & 62.00 & .270 \\
2. & Have unpredictable mood while at home & 69.00 & 58.25 & .083 \\
3. & Have no intention to interact with others & 65.50 & 55.50 & .095 \\
4. & Decides to sleep to avoid oppression & 68.75 & 61.00 & .233 \\
5. & Home condition leads to unoptimal works & 63.00 & 54.25 & .130 \\
6. & Feel too many people stays at home & 87.75 & 68.75 & $.005^{* *}$ \\
7. & Feeling annoyed when get visited by neighbours, house & 68.75 & 61.00 & .208 \\
\hline
\end{tabular}

Note: $* *)$ significant at $\mathrm{p}<0.01$

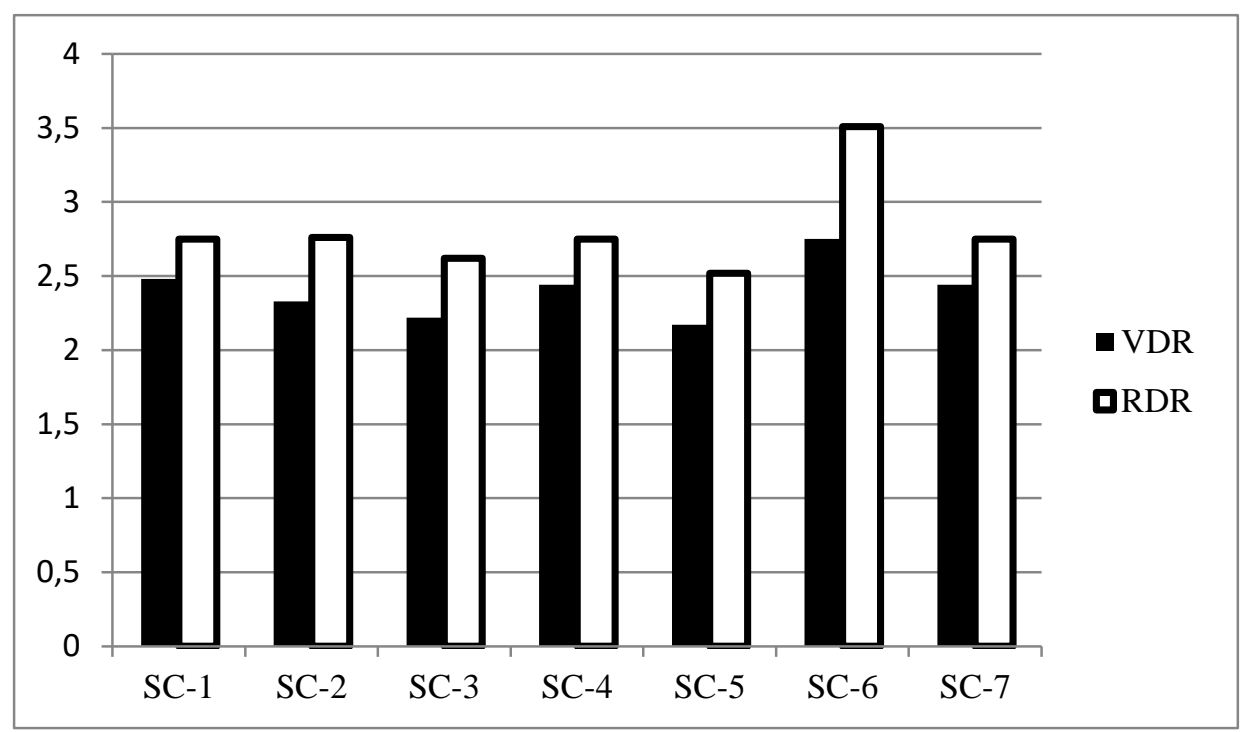

Figure 1. Distribution of average scores of the social aspect of crowding in two RDR and VDR. Notes: SC$1=$ Child becomes more aggressive; SC- $2=$ Have unpredictable mood while at home; SC- $3=$ Have no intention to interact with others; $\mathrm{SC}-4=$ Decides to sleep to avoid oppression; SC-5= Home condition leads to unoptimal works; SC-6= Feel too many people stays at home $(* *<0.005)$; SC$7=$ Feeling annoyed when get visited by neighbours, house is getting more full than usual

\section{Privacy}

Figure 2 below showed that privacy efforts in RDR families greater than in VDR families, especially significantly different in the acquisition efforts of non-physical environment. However, the non-physical dimension of privacy is more often done by families in the rather dense area (RDR). 


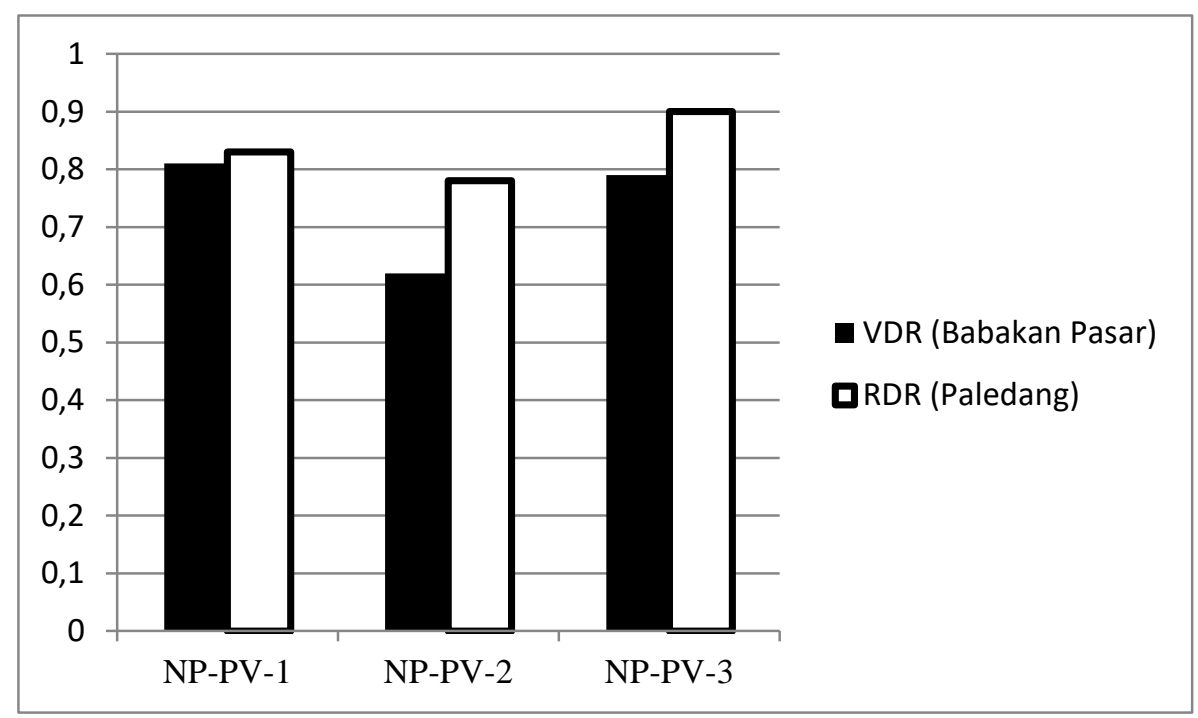

Figure 2. Distribution of item question of non-physical environment of privacy by density region. Notes: NP-PV-1= Speaking to another family member in very low voice tone; NP-PV-2= Using face expressions to give a "I don't want to be bothered" sign; NP-PV 3= I don't want to talk much about myself

\section{Family Stress Management}

\section{Family Stressor}

The study results (Table 4) indicate the families in the RDR have a higher source of stress (mainly due to financial and business). The total sources of stress in the RDR families significantly higher $(\mathrm{P}$-value $<0.05)$ than families in VDR. Stressor dimensions include the tension between husband and wife dimension, family problems and business dimension, dimensional changes and labor issues, as well as dimension of illness and family care do have significant differences (P-value 0.028; 0.000; 0.011; 0.012) in both regions, but more often felt by families in the RDR.

\section{Coping Strategies}

The results from Table 4 showed that coping strategies in both regions have significant differences ( $p$-value 0.027 ), whereas families more often do the coping strategies in RDR. Further descriptive analysis showed that coping strategies of emotional and psychological dimensions interpreted as the belief that the problem will pass and all will run smoothly, carried out three of the four families in RDR, as well as more than two-thirds of the families in the VDR. Moreover, the family's various coping strategies, which mostly (performed by two of the three families) are 'to remind myself that I am strong' and 'the belief that the problems will go away. The other coping strategy done by 40 per cent of families in both groups was watching TV, while the rest of the coping strategies are carried out only by a few families. 


\section{Symptoms of Stress}

In this study, the symptoms of stress include physical and psychological aspects. Families in RDR experienced physical symptoms of stress (malaise) higher (p-value 0.042) compared to the VDR families, but there is no significant difference in psychological stress symptoms in the two groups. On the other side, psychological stress symptoms (mood) in the two regions showed no real difference. Interestingly, families in both regions have almost similar psychological and physical symptoms of stress, as presented in Figure 3.

Table 4. Percentage of component of family stress management by density area and the result of comparison test

\begin{tabular}{llccc}
\hline No & Variables & RDR & VDR & P-Value \\
\hline 1 & Stressor : & & & \\
& a. Strain in the family & 44.60 & 35.24 & $.028^{*}$ \\
& b. Financial and business & 39.21 & 23.01 & $.000^{* *}$ \\
& c. Work \& family stressor & 21.17 & 13.97 & $.011^{*}$ \\
& d. Sickness and Family Care & 14.96 & 7.46 & $.012^{*}$ \\
2 & Coping Strategy & 36.57 & 29.02 & $.027^{*}$ \\
3 & Symptom of Stress & 54.67 & 54.22 & $.042^{*}$ \\
& a. Physical stress & 52.87 & 51.18 & .194 \\
\hline
\end{tabular}

Note: $* *)$ significant at $\mathrm{p}<0.01, *)$ significant at $\mathrm{p}<0.05$

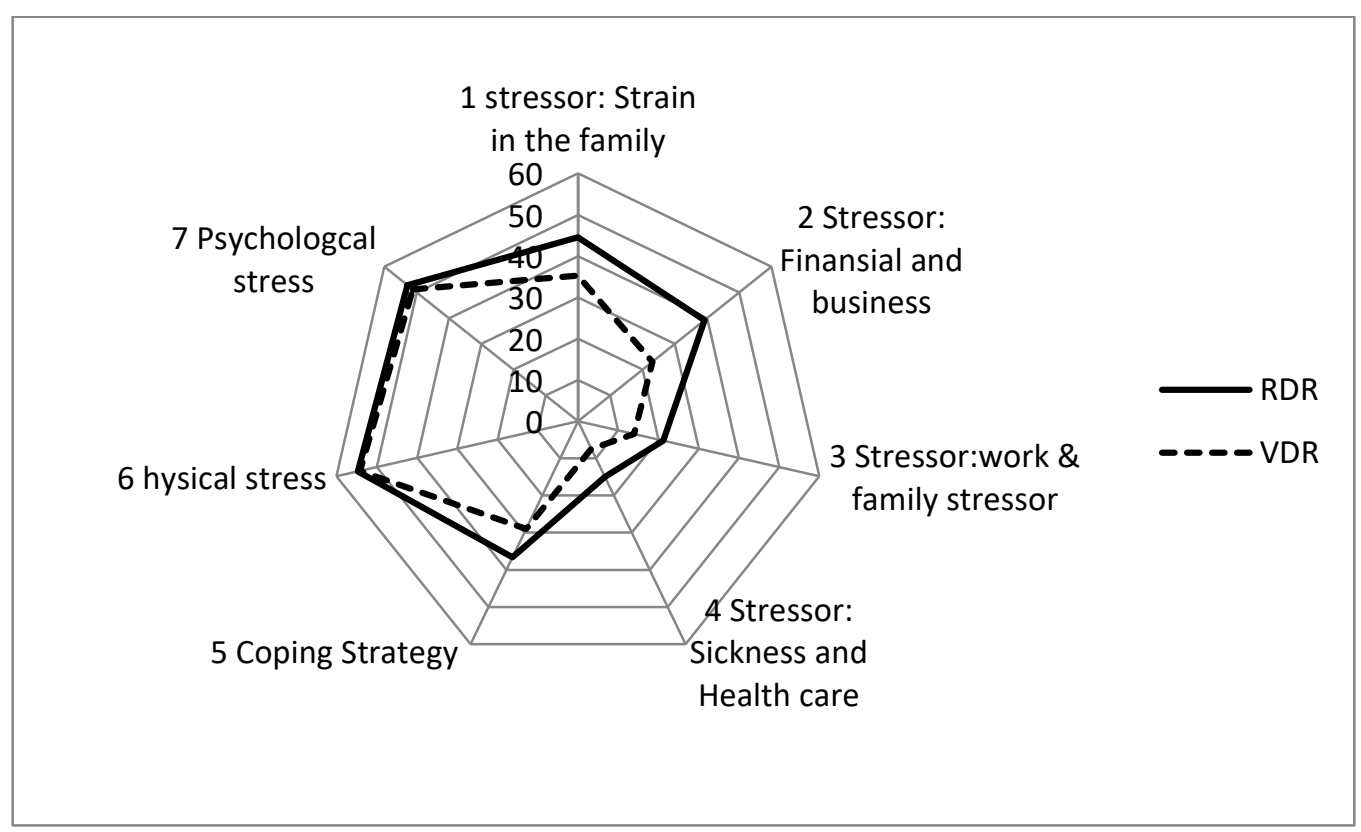

Figure 3. Component of family stress management according to density area

Further analysis conducted showed that more than 50 percent of families felt they were experiencing other physical symptoms, such as heart palpitations and becoming calmer. Psychological symptoms of stress perceived by more than 60 per cent of families in both regions are: prolonged sad; demoralized, and easily upset. While the other psychological 
symptoms recognized by more than 50 per cent of families are: feeling gloomy and melancholy; prone to anxiety, and worry. Additionally, more than two thirds $(71.43 \%)$ of RDR families chose to stay home when experiencing stress, whereas families in dense regions (VDR) felt difficulties in concentrating and experienced insomnia (67.94\%). More than two-thirds of the families in the rather dense area $(68.25 \%)$ and the very dense area $(69.52 \%)$ became more irritable when subjected to stress.

\section{Family Well-being}

1. Objective Welfare of Family

Table 5 showed that the overall objective welfare of the family in RDR higher (Pvalue 0.012) compared to the VDR families. However, three of the five components of objective welfare (education, housing, health) were significantly different. Families in RDR has higher housing and health compliance than VDR families, but the study found that families in VDR had higher education fulfilment than RDR families.

Deeper descriptive analysis showed that many families living in marginal settlements do not fulfil the standard of density ( $>8 \mathrm{~m}^{2} /$ capita). Moreover, spacious home in both regions has significant differences (p-value 0.007), where families in the rather dense area (RDR) has a larger house than in the very dense region (VDR). There are no differences in fulfilment of the diversity of food consumption every day (a full meal of rice, side dishes, vegetables and fruit) in two groups of families. However, the level of compliance in the family is still relatively low.

\section{Subjective Welfare of Family}

In contrast to the objective well-being of families, the results from Figure 4 showed that subjective well-being of families in the VDR higher (P-value 0.034) compared to the RDR families, particularly on the subjective well-being of the economic dimension. Over the various components of subjective well-being, the highest dissatisfaction perceived owns savings. Families in marginal settlements are not mostly satisfied with the status of current savings, with a note that families in RDR have a higher dissatisfaction (p-value $<0.004$ ) than families in VDR.

Table 5. Compliance (\%) of family welfare according to the density of the area and the results of comparison test

\begin{tabular}{rlrrr} 
No. & Variables & RDR & \multicolumn{1}{c}{ VDR } & P-value \\
\hline & Objective welbeing & $\mathbf{6 6 . 4 0}$ & $\mathbf{5 8 . 8 6}$ & $\mathbf{. 0 1 2 *}$ \\
1 & Food & 41.27 & 30.95 & .098 \\
2 & Clothes & 77.78 & 73.55 & .352 \\
3 & House & 60.71 & 49.60 & $.028^{*}$ \\
4 & Basic Education & 87.30 & 100.00 & $.003^{* *}$ \\
5 & Basic Health & 75.40 & 62.70 & $.029^{*}$ \\
\hline & Subjective welbeing & 62.96 & 68.53 & $.034^{*}$ \\
1 & Economic dimension & 44.53 & 53.41 & $.006^{* *}$ \\
2 & Social Dimension & 68.50 & 72.62 & .142 \\
3 & Psychological Dimension & 36.42 & 37.55 & .868 \\
\hline Note: $\left.{ }^{* *}\right)$ significant at $\left.\mathrm{p}<0.01,{ }^{*}\right)$ significant at $\mathrm{p}<0.05$ & & &
\end{tabular}




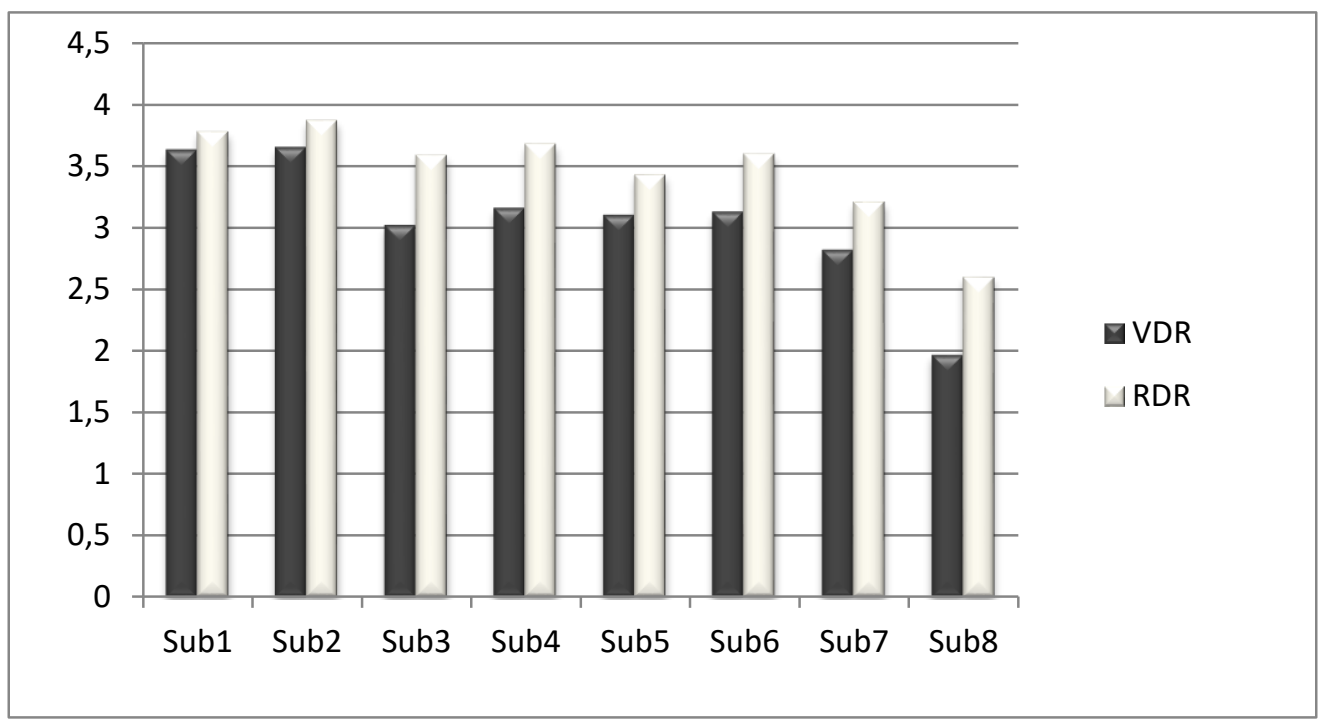

Figure 4. Compliance (\%) of physical-economy dimension of subjective family welfare according to the density of area and the result of different test. Notes: Sub1= satisfaction with food consumption; Sub2= the satisfaction of the clothes that are owned and used; Sub3= the satisfaction of the condition of the house occupied; Sub4= satisfaction with the ability to pay for health; Sub5= satisfaction with the ability to finance a child's education; Sub6 $=$ the satisfaction of the income earned by that time $(* 0.038)$; Sub7 $=$ the satisfaction of the assets or property owned; Sub8= satisfaction of personal-owned savings $(* *<0.004)$

\section{Discussion}

Marginal settlements in the middle of cities are prone to higher risks, including slope areas where there are more slum, fragile, poor sanitation, and higher density than others (Sunarti, Fithriyah, \& Ulfa, 2019). Attention to the home environment is important as inadequate housing conditions tend to be associated with slums, social morbidity, and health. In contrast, good homes are related to good health and social conditions (Wilner and Walkey in Melson, 1980). In general, density is closely related to crowding (Sarwono, 1992). High density correlates with satisfaction (Jacinto \& Mendieta, 2002). The density that occurs in the home gives the crowding perception resulting in low satisfaction and privacy of family members (Halim, 2008). Crowding contributes to the low quality of life, trauma in children, the emergence of the disease, and can cause excessive interaction, which all affect the family's function (Melson, 1980). Population density and one-room occupancy are significantly positively related to population density (Mansour \& Mostafa, 2018). The density descriptive analysis results show that families in RDR can acquire more land for housing (compared to VDR). So that even they have a larger family size (5 people with a range of 3-10 people compared to 4 people with a range of 3-8 people in the VDR), causing lower family density in the RDR $(11.35 \mathrm{~m} 2$ compared to $8 \mathrm{~m} 2$ in the VDR $)$. The lower the density causing RDR family still can accommodate extended families living together (compared to families living in the VDR). The number of families in RDR is higher than families in VDR.

In this study, high density does not automatically lead to crowding, according to Chan (1999), who indicated that residents who occupy a constrained space do not necessarily feel crowded. Crowdedness is high because of dissatisfaction with the physical environment 
rather than the quantity of space. That explained the privacy, that is, between space and crowding, has an indirect-moderate effect. According to Holahan in Sarowono (1992) explains that the crowd of individuals in the family is perceived to have a negative impact, such as the impact of disease and social pathology, physiological reactions (increased blood pressure), physical disease (psychosomatic). Also increased mortality and social pathology (increased crime, suicide, mental illness and delinquency, as well as social behaviour (aggression, withdrawal from the social environment, unhelpful behaviour, tendency to see the bad side of others). This also results to worse outcomes obtained and a tendency of feeling down.

These conditions, in turn, affects family function (Melson, 1980). For example, inappropriate home conditions with inadequate space for family members would obstruct each personal privacy in the family. Privacy is an important component in the family because it identifies and evaluates themselves and develops self-esteem (Sarwono, 1992; Melson, 1980). If the privacy function is continuously disturbed, there will be a process of social nudity, i.e. when everyone knows about the secret itself, causing embarrassment to face others and become de-individualization.

Efforts for privacy in RDR families are greater than in VDR families, especially significantly different in obtaining a non-physical environment. There is a very real difference (between RDR and VDR family) in family member's unwillingness to be disturbed (by other peoples) by limiting the information up to others and always spoke quietly. This is done because the standard of home density per capita of marginal families has not been met, thus encouraging their behaviour to get privacy by using measures that do not require space. These results are consistent with research conducted by Razali (2013) which states that extensive housing or home related to one manages privacy.

When a person feels that the individuals have no longer appreciated the condition, they are no longer care to value themselves or others (Sarwono, 1992). Whereas if there is no privacy in the family unit, it will lead to agonized interaction. Problems also arise due to an unhealthy environment for the family's privacy regarding the child's condition and autonomy within the family (McMullen, 1992). Therefore, the families who live in marginal settlements must be able to manage the environment with good physical conditions to have more supporting and comfortable housing conditions. Each member of the family is given and given some privacy. Therefore, the level of subjective well-being can be highly achieved.

The results of this study were to elaborate "spatial environment of home, stress management, and family welfare" indicates the absence of patterns that establish linkages between density and crowding, as well as the efforts made to obtain privacy of family members, especially to the density of the area where the family lived. This is in accordance with Stokols (1972), who states that crowding measurement will still need to be developed further. Financial and business related stressors due to increased loans, medical expenses, children's education costs, food-use-home repairs, luxury purchases, home purchases or construction, late payment of necessities, efforts to maintain or improve welfare, decreased income, starting a new business. Elder, Conger, Foster, and Ardelt (1992) stated that the salary change experienced by families in marginal settlements as the effect of unstable occupation would lead to economic pressure. Stressor related work-family include: not work, changing jobs, lose or quit work, start or re-employment, work dissatisfaction, not in congruence with co-workers, heavy work responsibilities, moving house, got a new family 
member. Stressors are related to illness and family care from a seriously ill spouse, serious illness of a child, difficulties in child care, a close friend who is seriously ill, a physically disabled family member. Also difficult to care for family members with serious illnesses, provide financial assistance to sick relatives, and care for sick relatives; family members must be treated intensively. Moreover, as families invested more time for work responsibilities, family time and routines in poor families and families with unstable work were relatively low (Sunarti, 2019) as an effort to maintain their well-being.

Descriptive analysis indicated that the family had to adapt to multiple stressors. The data showed that only a few families were experiencing stress because family members did not work for a long time and family members lost their jobs. This indicates that the family was used to experiencing financial difficulties, which led to less high intensity of the symptoms of stress felt by families. Events that become such a family stressor was when the child was unobediant and when the child was seriously ill. These events provide the highest achievement scores of stress perceived by the family. This result indicates that the child is at the core of a family system, in line with Bronfenbrenner (1979) referred by Santrock (2007). However, only a few families felt stressed while there is an increase in the child's activity outside the home, although the outside home environment is not safe for children. This indicates that the family is no longer feeling worried at anytime the child is in unsecure place outside of home environment. In particular, children aged 3-5 years are still in great need of parental supervision to explore their curiosity outside the home located in marginal areas and prone to disasters.

The study results (Table 4) indicate the families in the RDR have a higher source of stress (mainly due to financial and business). In line with the results of research Sunarti and Junita (2011), the analysis results indicate the source of stress due to tension in the family and due to financial problems and the business providing the highest contribution to the total stressor. Changes in conditions (economic, political, weather) that adversely affect a decrease in family income are recognised as sources of stress perceived by many families. This is consistent with Herlanti, Sumarwan, and Uripi (1995), which states that the low income becomes a source of stress that contributes to the high symptoms of stress. Additionally, the unrecognized status of slums plays a central role in psychological distress (Subbaraman et al., 2014).

Families do coping strategies in the face of stressors. Coping strategies are active efforts of individuals and families as a unit to manage, adapt and cope with stressful situations (Sunarti 2013a). Sunarti et al. (2005) mention that high coping strategies can reduce the symptoms of stress, where Singh, Sharma, and Sharma (2011); Morimoto, Shimada, and Ozaki (2013) in his research indicates that stressors affect the selection of coping strategies. Lazarus and Folkman in Ozkan, and Kutlu (2013) proved that coping strategies affected by stress, whereas the higher goes the stress level or stressors, the more efforts in coping strategies must be done.

Family management to stressors produces stress levels, as measured from the symptoms (Sunarti, 2013a). Mirrowsky and Ross (1989) distinguished symptoms of stress based on two components, namely, component malaise and mood. Referring to Pestonjee and Pandey (2013), stress can lead to physical and psychological impacts on individuals. Another study conducted by Henley et al. (2014) found that socio-economic condition is one factor contributing to chronic stress. 
Objective welfare emphasizes the use of normative standards fulfilment of basic needs, including compliance with the need for food, clothing, housing needs, educational needs, and health needs, while subjective welfare focuses on the family satisfaction towards the fulfilment of their basic needs (Sunarti, 2012). Some identified objective well-being as an external aspect that develops from perception and one's evaluation of human society (Alatartseva \& Barysheva, 2015). Sunarti (2012) stated that the objective well-being can be assessed from the fulfillment of the density standard of homes. From this study, there is a significant difference in basic health compliance, where RDR achieved higher. This is in line with (Ezeh et al., 2017) that worse health occurred with people in slums than those in nonslum urban areas. Even though there is no significant difference in food compliance in this study, Rani et al. (2018) suggested that mental health problems related to stress management are associated with food insecurity, which can occur in families at informal settlements.

Subjective well-being is an important factor in the family, as it shows the overall evaluation of the achievement of a life lived (Diener, 1984). Various demographic factors, such as age, education, occupation, marital status and income, are important parts of subjective well-being (Diener, 1984; Oswald in Sarracino, 2008). The neighbourhood is also closely related to well-being (Halim, 2008). Subjective well-being or inner-well being is defined as a human, spiritual well-being associated with one's characteristics and features (Alatartseva \& Barysheva, 2015).

Families in marginal settlements are not mostly satisfied with current savings, especially in RDR area. Other studies (Sunarti, 2013a) showed a similar thing: the highest satisfaction of family is the ownership of savings. This situation shows that the income is not sufficient to cope with routine purposes, especially in the face of unexpected purposes. One more factor associated with dissatisfaction in regards to economic condition is the number of family members. Families with small numbers have greater opportunities to prosper because of fewer family dependents (Hatmadjil \& Anwar in Iskandar, 2007). The higher the family income or increase would make the family meet the family's needs, caused the family gains higher satisfaction (Suandi, 2007). Other explanations showed that low satisfaction on family ownership savings in two areas is related to the number of families who work in the informal sector, making no guarantee on the family's financial stability. This is consistent with Sunarti (2013b) research, which states that the effect on the stability of family welfare work (total, subjective, and objective).

Moreover, suppose it is in relation to the linkage patterns of spatial environment of the home with stress management and family welfare, such as on community and national levels. In that case, it is important to identify objective well being as an effort to find a way to achieve a higher level of Human Development Index and, in the end, join with the group of countries characterized by a very high HDI (Ivković, Ham, \& Mijoč, 2014). Variables such as subjective well-being can also help improve the delivery of services for human development in policies (UNDP, 2017). Based on this matter, more advanced research is needed to involve a variety of other variables and more sophisticated analysis and more representative sample size to obtain stronger results.

Limitations of this study evolved around its purposive sampling technique in selecting the locations of marginal settlements. Additionally, the use of samples consisting of intact families with children aged 3-5 years old resulted in this study being unable to be generalized, especially to families with broader characteristics located in different areas. 


\section{Conclusion and Recommendation}

\section{Conclusion}

The comparison results indicated that RDR and VDR families have significant differences in a spatial environment, stress management, and family welfare. This study also showed that the social aspect of the crowd and efforts to obtain privacy using the nonphysical environment were significantly different. In addition, having a higher average score achieved by RDR families and the social aspect of the crowd "felt too many people staying at home". Privacy efforts by RDR families were greater than VDR families and were found significantly different in the acquisition efforts of non-physical environments. Moreover, RDR families have higher stressors (particularly significantly different in financial and business aspects), higher coping strategies, and higher physical symptoms than VDR families. In terms of family welfare, objective well-being is higher in RDR, but the opposite for subjective well being. Basic education, house and basic health compliance components on objective well-being were found significantly different. VDR families with higher score subjective well-being are significantly different specifically on economic dimension than RDR families.

Families in RDR allow obtaining broader land for housing (compared to families in VDR), causing lower density and a larger average family size. However, the family still can accommodate extended families living together. With lower density, however, RDR families have high crowding, which means that the family members should put more efforts to obtain personal privacy, especially in non-physical aspects. Furthermore, it was in line that the families in the RDR had higher stress sources (mainly due to financial and business) that led them to put more effort into coping strategies. However, they were still having higher symptoms of stress (especially physical stress). In line with these results, when using the classification of physical-social-psychological well-being, families in RDR have higher physical well-being. Still, they have lower social and psychological well-being than in VDR families.

\section{Recommendation}

This study provides data and portraits of some aspects of the life of families living in marginal areas in Bogor City (West Java Province) as one of the supporters of the metropolitan cities in Indonesia. Data and information are expected to be material to the government and stakeholders of families' development in providing relevant policy and programs in an effort to increase the resilience and life quality of the family. Moreover, this study provides a foundation to further research about marginal settlements with a broader sample of family characteristics in different metropolitan locations with a deeper analysis of the correlation between spatial environment, stress management and family welfare in the future. 


\section{References}

Alatartseva, E., \& Barysheva, G. (2015). Well-being: Subjective and objective aspects. Procedia - Social and Behavioral Sciences, 166, 36-42. Doi: https://doi.org/10.1016/j.sbspro.2014.12.479

Anjanie, F. F. (2006). Pengaruh kepadatan terhadap interaksi sosial warga rumah susun apron Kemayoran (The influence density on social interaction of Kemayoran apron flats residents) (Undergraduate theses, Bogor Agricultural University, Indonesia). Retrieved from http://repository.ipb.ac.id/jspui/bitstream/123456789/50999/1/A06ffa1.pdf

Baquyatan, S. M. (2015). The impact of housing issue on the well-being of middle-income group. Mediterranian Journal of Social Sciences, 6(6 S1), 522-527. Doi: http://dx.doi.org/10.5901/mjss.2015.v6n6s1p522

Bonnefoy, X. (2007). Inadequate housing and health: An overview. International Journal Environment and Pollution. 30(3-4), 411-429.

BPS Kota Bogor. (2014). Jumlah dan persentase penduduk miskin, garis kemiskinan, indeks kedalaman kemiskinan, dan indeks keparahan kemiskinan menurut provinsi September 2013 (Number and percentage of poor people by province). Retrieved from http://www.bps.go.id/tabel_excel/indo_23_1.xls.

Chan, Y. (1999). Density, crowding, and factors intervening in their relationship: Evidence from a hyper-dense metropolis. Social Indicators Research, 48(1), 103-124. Retrieved from http://www.jstor.org/stable/27522404

Diener, E. (1984). Subjective well-being. Psychological Bulletin, 95(3), 542-575. Doi: http://dx.doi.org/10.1037/0033-2909.95.3.542

Elder, G., Conger, R., Foster, E., \& Ardelt, M. (1992). Families under economic pressure. Journal of Family Issues, $13(1), \quad$ 5-37. https://doi.org/10.1177/019251392013001002

Ezeh, A., Oyebode, O., Satterthwaite, D., Chen, Y.F., Ndugwa, R., Sartori, Jo., Mberu, B., Melendez-Torres, G. J., Haregu, T., Watson, S. I., Caiaffa, W., Capon, A., \& Lilford, R. (2017). The history, geography, and sociology of slums and the health problems of people who live in slums. The Lancet 389 (10068), 547-558. Doi: http://dx.doi.org/10.1016/S0140-6736(16)31650-6

Halim, D. K. (2008). Psikologi lingkungan perkotaan (Urban environment psychology). Jakarta, Indonesia: Bumi Aksara.

Henley, P., Lowthers, M., Koren, G., Fedha, P. T., Russell, E. VanUmm, S., Arya, S., Darnell, R., Creed, I. F., Trick, C. G., \& Bend, J. R. (2014). Cultural and socioeconomic conditions as factors contributing to chronic stress in sub-Saharan African communities. Canadian Journal of Physiology and Pharmacology, 92, 725-732. Doi: http://dx.doi.org/10.1139/cjpp-2014-0035

Herlanti, Y., Sumarwan, U., \& Uripi, V. (1995). Faktor-faktor yang mempengaruhi gejala fisik dan gejala jiwa stress pada ibu bekerja dan ibu tidak bekerja (Factors affecting the physical-mental symptoms of stress of mothers). Jurnal Media Gizi dan Keluarga, 18-26. 
Iskandar, A. (2007). Analisis praktek manajemen sumberdaya keluarga dan dampaknya terhadap kesejahteraan keluarga di Kabupaten dan Kota Bogor (Analysis of family resource management practices and their impact on family well-being in the county and the city of Bogor). Sodality: Jurnal Transdisiplin Sosiologi, Komunikasi, dan Ekologi Manusia 1(3), 295-312. Doi: http://dx.doi.org/10.22500/sodality.v1i3.5924

Ivković A., Ham, M., \& Mijoč, J. (2014). Measuring objective well-being and sustainable development management. Journal of Knowledge Management, Economics, and Information Technology, 4(2).

Jacinto, L.G., \& Mendieta, H. (2002). Multiple effects of community and household crowding. Journal of Environment Psychology, 22(2), 233-246. Doi: https://doi.org/10.1006/jevp.2002.0236

Lirebo, D. (2006). Informal settlements in Addis Ababa. UDP-705 Housing in Urban Context (Addis Ababa University, Ethiopia). Retrieved from http://etd.aau.edu.et/bitstream/handle/123456789/496/Daniel\%20Lirebo.pdf?seque nce $=1 \&$ isAllowed $=\mathrm{y}$

Mansour, S., \& Mostafa, M. M. (2018). Residential urban overcrowding in Alexandria, Egypt: A spatial econometrics analysis. African Journal of Business and Economic Research (AJBER), 13(1), 157-176.

Maryam, S. (2010). Pengaruh karakteristik sosial ekonomi terhadap strategi coping keluarga pasca gempa dan tsunami di Nanggroe Aceh Darussalam (The effects of socioeconomic characteristics to coping strategy in family post-earthquake and tsunami in Nanggroe Aceh Darussalam). Jurnal Aplikasi Manajemen, 8(2), 546-560.

McCubbin, H. I., \& Thompson, A. I. (1987). Family assessment inventories for research and practice. Madison, USA: The University of Wisconsin-Madison.

McMullen, J. G. (1992). Privacy, family autonomy, and the maltreated child. Marquette Law Review, (75)3, 569-598.

Melson, G. F. (1980). Family and environment: An ecosystem perspective. Minneapolis, USA: Burgess Publishing Company.

Milligan, S., Fabian, A., Coope, P., \& Errington, C. (2006). Family well-being indicators from the 1981-2001 New Zealand censuses. New Zealand: Statistics New Zealand. Retrieved from http://archive.stats.govt.nz/ /media/Statistics/browsecategories/people-and-communities/families/family-wellbeing/family-wellbeingreport-2006.pdf

Mirrowsky, J., \& Ross, C. E. (1989). Social causes of psychological distress. New York, USA: Aldine de Gryuter.

Morimoto, H., Shimada, H., \& Ozaki, K. (2013). Does stressor evaluation mediate sociocultural influence on coping selection? An investigation using Japanese employees. International Journal of Stress Management, 20(1), 1-19. Doi: http://dx.doi.org/10.1037/a0031432

Nagasawa, N., Yamaguchi, R., Kato, R., Tanabe, S. (2018). Longitudinal study of housing for the promotion of health and well-being using a covariance structure model to identify the causal relationships between satisfaction with living environment, stress, and chronic low back pain. Japan Architectural Review, 1(1), 154-166. Doi: https://doi.org/10.1002/2475-8876.10018 
Nkosi, V., Haman, T., Naicker, N., \& Mathee, A. (2019). Overcrowding and health in two impoverished suburbs of Johannesburg, South Africa. BMC Public Health, 19(1). Doi: https://doi.org/10.1186/s12889-019-7665-5

Ozkan, S., \& Kutlu, Y. (2010). Evaluation of coping strategy, social support, and depressive symptoms in spouse of patients with hematological cancer. Turk J Med Sci, 40(6), 925-936. Doi: 10.3906/sag-0904-6

Pestonjee, D. M., \& Pandey, S. (2013). Stress and work, perspectives on undertstanding and managing stress. California, USA: SAGE Publications Inc.

Poedjioetami, E. (2005). Lokasi strategis sebagai potensi ketahanan hidup di permukiman marjinal: Studi kasus permukiman sepanjang rel kereta api (KA) dari lintasan Jalan Bung Tomo - Jalan Jagir Wonokromo Surabaya (Strategic location as survival potential at marginal settlements: Case Study by the railway-settlements Bung Tomo - Jagir Wonokromo Surabaya route). Jurnal Rekayasa Perencanaan, 2(1), 28-41.

Rani, D., Singh, J. K., Acharya, D., Paudel, R., Lee, K., \& Singh, S. P. (2018). Household food insecurity and mental health among teenage girls living in urban slums in Varanasi, India: A cross-sectional study. International Journal of Environmental Research and Public Health, 15 (8), 1585. Doi: https://doi.org/10.3390/ijerph15081585

Razali, N., \& Talib, A. (2013). Aspect of privacy in muslim Malay Traditional dwelling interior in Melaka. Procedia - Social and Behavioral Sciences. 105, 664-66. Doi: https://doi.org/10.1016/j.sbspro.2013.11.067

Rosino, M. (2016). ABC-X model of family stress and coping. The Wiley Blackwell Encyclopedia of Family Studies. New Jersey, USA: John Wiley \& Sons, Inc. Doi: https://doi.org/10.1002/9781119085621.wbefs313

Santrock, J. W. (2007). Perkembangan anak Edisi ke 11 Jilid 2 (Child development) (2 ${ }^{\text {nd }}$ ed.). Jakarta, Indonesia: Erlangga.

Sarracino, F. (2008). Subjective well-being in low income countries; positional, relational and social capital components. Studi e Note in Economia. 13(3), 449-477.

Sarwono, S. W. (1992). Psikologi lingkungan (Environmental psychology). Jakarta, Indonesia: Grasindo.

Singh, C., Sharma, S., \& Sharma, R. (2011). Level of stress and coping strategies by nursing interns. Nursing and Midwifery Research Journal, 7, 152-160. Doi: $10.12816 / 0032673$

Stokols, D. (1972). On the distinction between density and crowding: Some implications for future research. Psychological Review, 79(3), 275-277. Doi: http://dx.doi.org/10.1037/h0032706

Suandi. (2007). Modal sosial dan kesejahteraan ekonomi keluarga di daerah pedesaan dan provinsi Jambi (Social capital and economic welfare of families in rural areas of Jambi provinces) (Doctoral theses, Bogor Agricultural University, Indonesia). Retrieved from https://repository.ipb.ac.id/handle/123456789/40884

Subbaraman, R., Nolan, L., Shitole, T., Sawant, K., Shitole, S., Sood, K., Nanarkar, M., Ghannam, J., Betancourt, T. S., Bloom, D. E., \& Patil-Deshmukh, A. (2014). The psychological toll of slum living in Mumbai, India: A mixed-methods study. Social 
$\begin{array}{lllll}\text { Science } \quad \& \quad \text { Medicine, } & \text { 119; }\end{array}$ http://dx.doi.org/10.1016/j.socscimed.2014.08.021

Sunarti, E. (2012). Keragaan ketahanan keluarga Indonesia: Pembangkitan teori (Middle Range Theory) dan rumusan kebijakan ketahanan keluarga Indonesia (Family strength of Indonesian family emerging Middle Range Theory and formulating the family policy). Hibah Kompetensi DP2M Dikti Research Report.

Sunarti, E. (2013a). Work Stability, economic pressure, and family welfare in Indonesia. Paper Presented at $5^{\text {th }}$ International Community Work and Family Conference, Sydney, Australia.

Sunarti, E. (2013b). Ketahanan keluarga (Family strength). Bogor, Indonesia: IPB Press.

Sunarti, E. (2019). The portrait of the value and management of family time. Pertanika Journal of Social Science \& Humanities, 27(2), 993-1006.

Sunarti, E., \& Junita, S. (2011). Pengelolaan stress pada keluarga korban bencana alam di Kabupaten Bogor. 120 (Stress management in family victims of natural disasters in Bogor). Jurnal Ilmu Keluarga dan Konsumen, 4(2), 111-120.

Sunarti, E., Fithriyah, A. F., \& Ulfa, M. (2019). Family-friendly kampong (FFK) modelling: developing urban resilience in disaster-prone area. Equity, Equality, and Justice in Urban Houseing Development, KnE Social Sciences, 2019, 243-255. Doi: https://doi.org/10.18502/kss.v3i21.4972

Sunarti, E., Ifada, Q., Ika, D., \& Sri, H. (2005). Ketahanan keluarga, manajemen stress, dan pemenuhan fungsi ekonomi dan fungsi sosialisasi keluarga korban kerusahan Aceh (Family strength, stress management, and compliance of economic and social of family affected by Aceh disaster). Media Gizi dan Keluarga, 29(1), 41-49.

Surtiani, E. (2006). Faktor-faktor yang mempengaruhi terciptanya kawasan pemukiman kumuh di kawasan pusat kota, studi kasus: kawasan Pancuran, Salatiga (Factors affecting the creation of slums areas in the city center region, case study: Kawasan Pancuran, Salatiga) (Masters theses, Universitas Diponegoro, Indonesia). Retrieved from http://eprints.undip.ac.id/15530/

UNDP. (2017). Happiness, well-being, and human development: The case for subjective measures. 2016 UNDP Human Development Report Background Paper. Retrieved from http://hdr.undp.org/sites/default/files/anand_template_rev.pdf

UNHabitat. (2016). Informal settlements. Habitat III Issue Papers 22. Retrieved from https://unhabitat.org/habitat-iii-issue-papers-22-informal-settlements/

WHO. (2003). People living in informal settlements. Retrieved from: http://www.who.int/ceh/indicators/informalsettlements.pdf

Zuhara, I., Muflikhati, I., \& Krisnatuti, D. (2017). Stressor, social support, coping strategy, stress and life satisfaction of married woman student. Journal of Family Sciences, 2(1), 1-14. 